\title{
Interactive Media Development of Procedures for Prayer (Tara Shalat) Based on Adobe Flash in Improving the Skills of Madrasah Ibtidaiyah Prayers
}

\author{
Guntur Cahyono \\ IAIN Salatiga \\ gunturcy@iainsalatiga.ac.id
}

\begin{abstract}
This research aims to develop interactive learning media for adobe flashbased prayer procedures/Tara (Tata Cara Shalat). Interactive media can develop prayer skills that are taught in the habituation process since the first grade of Madrasah Ibtidaiyah (MI). This research used development research $(R \& D)$ methods. The development process in this study reached the stage of the formative evaluation process consisting of three steps, namely individual prototype material trials, small group trials, and field tryouts. This field trial involved subjects in a larger class, involving 15-30 (a whole class of learners) or larger groups, namely the available classes. The results of this field trial were used to make a product, material, or final design revisions. Interactive learning media can solve the problem of prayer skills regarding recitation and movement of prayer. Thus, interactive learning media made it easier for students to understand the procedures for prayer quickly; besides, the learning process will be more enjoyable.
\end{abstract}

Keywords: interactive media, procedures for prayer, adobe flash

\section{INTRODUCTION}

National Education System Law No. 20 of 2003 states that learning is a process of interaction of students with educators and learning resources in a learning environment. Learning as a learning process built by teachers to 


\section{Mudarrisa: Jurnal Kajian Pendidikan Islam, Vol. 11, No. 2, 2019}

develop thinking creativity that can improve students' thinking abilities, and can improve the ability to construct new knowledge to increase good mastery of subject matter.

The learning process requires the teacher to know the basic abilities possessed by students include basic abilities, motivation, academic background, economic background, and so forth. Teacher readiness to recognize the characteristics of students in learning is the main capital, which is very important in the delivery of learning materials and is an indicator of the success of learning implementation. According to Sugandi, et al. (2000: 25), the characteristics of learning include: 1) Learning is done consciously and planned systematically; 2) Learning can foster student attention and motivation in learning; 3) Learning can provide interesting and challenging learning material for students; 4) Learning can use appropriate and interesting learning aids; 5) Learning can create a safe and pleasant learning atmosphere for students; 6) Learning can make students ready to accept lessons both physically and psychologically.

The learning process here includes prayer learning skills. Prayer material is a habituation learning activity carried out at school. It relates to the position of prayer to be one of the pillars of Islam, which is done as much as five times a day on obligatory prayers. Schools have an essential role in the formation of the habit of prayer after the role of parents. The school's role is to instill the correct concept of the procedure of prayer in accordance with that conveyed by the Prophet Muhammad (Peace Be 
Upon Him).

This concept implantation is carried out both in the learning process in the classroom and practice in school because prayer is not just moving the limbs, but there are recitations as well as conditions and pillars that need to be understood and carried out by every Muslim. In addition, prayer has various terms that children need to know, such as takbiratul ihram, i'tidal, ruku', sujud, and so on. Thus, the skills of prayer are understood as procedures for doing prayer, together with knowing the terms in prayer.

To support it, teachers need media that can function to instill prayer skills correctly and adequately. Fostering the skills of prayer is very important for children because the right prayer will make a child pious and awake from heinous and unjust acts. Proper prayer development for children influences children to adulthood, and if it is not considered, then the wrong prayer practice will always be carried out by children. As a result, children are always in error in performing prayers (Mujiburrachman, 2016: 187).

Meanwhile, the interaction between educators and students occurs in the teaching and learning process in schools. Teachers, as educators, are implementers of the educational process that have an essential role in achieving educational goals. Educators have a critical position in education that is as a facilitator and supervisor; therefore, educators are required to be creative and sensitive to characteristics and psychic (Hamidi, 2017: 


\section{Mudarrisa: Jurnal Kajian Pendidikan Islam, Vol. 11, No. 2, 2019}

111). Therefore, media development is the most crucial part of creating a fun learning so that learning objectives can be achieved.

The development of computer and internet information technology has also changed the pattern of learning from traditional to modern learning. The use of instructional media has begun to take advantage of the development of more sophisticated computer programs. Computer programs can be used to support the teaching and learning process. It can be done starting from the media in the form of interactive games, video, visual media, audio media, and audio-visual mix in the form of short films or documentaries (documentation).

However, the media that are usually made by teachers are still oneway. With the development of information technology, teachers and media practitioners are encouraged to develop interactive learning media by utilizing computers as interactive learning media in Islamic Religious Education (PAI) learning. It is to be relevant because this interactive learning media is intended to facilitate students in understanding PAI learning materials. Moreover, it is because interactive learning media can present material with interactive multimedia concepts (consisting of text, sound, images, animation, and video) (Hamidi, 2017: 111).

According to Arsyad (2014: 3), the term 'media' comes from the Latin medius, which literally means middle, intermediary, or introduction. According to Arabic, the media comes from the word wasaail, which means the delivery of the message from the sender to the recipient of the message. The media, if understood broadly, are humans, materials, or 
events that build conditions that make students able to obtain knowledge, skills, or attitudes. In this case, the teacher, textbooks, and the school environment are learning media. More specifically, the notion of media in the teaching and learning process tends to be interpreted as graphic, photographic, or electronic tools for capturing, processing, and rearranging visual or verbal information.

According to Adriyanto (2010), one of computer application that can be used as an interactive learning media in the learning process of Islamic Religious Education is Adobe Flash Professional CS6. It is a vector-based two-dimensional (2-D) animation program that has been widely used by animators to create animations, one of which is to create multimedia presentations. Pictures, sounds, and videos can be inserted in slides (Hamidi, 2017: 111).

Research conducted by Hidayatul Maulidta, who developed interactive media based on Adobe Flash Professional to write exposition text, found the fact that there was a significant increase in grades when students used adobe flash interactive media. The test results showed that the media were effectively used in learning to write exposition text for grade III elementary school students. It can be proven by the results of tests on the final product trial that student learning outcomes have increased significantly, and students have been able to write exposition texts systematically (Hidayatul, 2018: 691).

The difference from this research was that the research conducted by Hidayatul did not reveal the name of the media developed. In contrast, 


\section{Mudarrisa: Jurnal Kajian Pendidikan Islam, Vol. 11, No. 2, 2019}

in this study, the authors used the name of the media, namely the interactive media TARA Shalat. Related research conducted by Atiaturrahmaniah and Doni Septu Marsa Ibrahim in the Development of Learning Media Based on Adobe Flash Professional with the Application of Van Hiele Theory revealed that Adobe Flash Professional media was created to facilitate the learning of geometry. Based on the results obtained, it indicates that the learning outcomes of students who get learning with the help of Adobe Flash Professional-based media are better than students who get learning without the help of learning media or get conventional learning (Atiaturrahmaniah \& Doni, 2017: 12). The difference of the research is that the research conducted by Atiaturrahmaniah \& Doni used the experimental class and the control class in the application of the developed Adobe Flash Professional interactive media. Both of the research gave the advantages in each subject. So that, it could be compared by their similarity. Meanwhile, research conducted by the author did not use the experimental class and the control class.

Many studies had shown that using computers to teach is better than using books, teachers, films, or other traditional methods (Alessi \& Trollip, 2001). Therefore, computers can be used to develop learning media in the world of education, so that it will be a means or tool in the learning process that is more effective in delivering subject matter and is efficient in allocating time and energy (Istiqlal, 2017: 45). 
Teachers should develop media so that the learning of prayer in schools is more leverage to encourage prayer skills for students. In the field observation activities at Madrasah Ibtidaiyah Muhammadiyah (MIM) Special Program (PK) Blimbing Gatak Sukoharjo, it was found some errors of movement and prayer recitations, which occurred in class 2 students. An evaluation was needed to look for learning concepts in terms of the media utilized. Students at MIM PK Blimbing Gatak Sukoharjo in prayer learning were more on learning practices. Therefore, the use and development of Adobe Flash Professional media were expected to be useful for correcting some errors in recitation and prayer movements.

By its benefits, Ely in Danim (1995: 13) mentions the benefits of the media in improving the quality of learning through increasing the speed of learning, and the media provides the possibility of individual learning so that they can correct each student's mistakes, the media as a basis for teaching in a scientific atmosphere, stability in the teaching and learning process. In addition, the media can increase the closeness of learning, and the media provide a broader presentation of learning not limited to the classroom.

Meanwhile, the teacher taught prayer more direct with practice in the prayer room or mosque in school without understanding the initial concept of prayer. At MIM PK Blimbing Gatak Sukoharjo, the children could not demonstrate the prayer adequately because it was more limited to practicing the prayer so that the recitations and prayer movements were not right and needed to be addressed. Thus, with this background, the 
researcher feels interested in developing interactive media based on Adobe Flash Professional that can support the learning process of prayer skills for MI students. This media would be used as a tool, as one of the processes to improve recitation and movement of prayer that have been carried out so far at MIM PK Blimbing Gatak.

\section{METHODS}

This research used the Research and Development method to produce specific products and test the effectiveness of these products. In carrying out research and development strategies to produce products in the form of interactive media for the Prayer Procedure/Tara Shalat, the development steps taken in this study started from analyzing the problem, then developing product designs in the form of Tara Prayer interactive media. The product design began with the making of a script from the material procedures for prayer. This script was developed in the form of visual media design and continued for media production. Design validation and revision were done at the beginning as part of the effectiveness of the making. The next stage was the media product trial for student use by looking at the input process from the teacher, the media expert, and the students themselves.

\section{DISCUSSION}

A critical study in the area of educational technology is the development of media. The development of science and technology is the most crucial foundation for the development of instructional media. The development of instructional media from print technology to the present time in 
computer technology has become the domain of educational technology studies in the process of media production. The development of computer technology has its influence on a variety of media production in various forms. Computers can produce interactive media. It has become an essential development for teachers and other education practitioners to produce innovative media in accordance with the development and needs of students.

According to Seels \& Richey (1994), development is defined as the process of translating design specifications into physical forms. The intended design specification is a product that is designed both at the macro level, such as programs and curriculum, as well as at the micro-level, such as modules, syllabus, and learning implementation plans. As for what is meant by a physical form in that definition refers to print technology, audiovisual technology, computer-based technology, and integrated technology (Yaumi, 2018: 82-83).

Similarly, Gustafson and Branch (2002) direct the definition of development to activities that refer to five categories, namely: (1) analyzing learning needs and conditions that occur, (2) designing a set of learning environments that are effective, efficient, and appropriate, (3) developing all aspects related to students and the management of materials, (4) implementation of materials that have been developed, (5) formative and summative evaluation of the results of development (Yaumi, 2018: 83).

\section{Interactive Media}

Learning media in the modern era contributed for the implementation of 


\section{Mudarrisa: Jurnal Kajian Pendidikan Islam, Vol. 11, No. 2, 2019}

good learning and the achievement of learning objectives significantly. Teachers had to adapt the situation by using the smart technology to increase student proclivity. The real condition in the field is that rigid learning in class makes children bored in the learning process. The emergence of internet information technology opened much information that can be obtained by students. Information from the internet will continue for twenty-four hours. When the teaching and learning process does not utilize and develop learning media, they will not be able to convey the material effectively.

Media is an indispensable component in the learning process; in this case, the media is used to channel messages from the sender (communicator/teacher/media) to the recipient (communicant/student) to stimulate the thoughts, feelings, concerns, or wishes of students so that later will encourage the learning process (Nelwati et al., 2019: 5). The media contained and carried messages or information to the recipient; messages and information carried by the media can be simple messages and can also be complex media; however, the most important is that the media is prepared to meet the learning needs and abilities of students so that they can actively participate in the learning process (Cahyono, 2019: 13).

Seels \& Glasgow (1990) in Arsyad (2014: 35-36) classify interactive media as the choice group of the latest technological media. The latest technological media itself can be divided into (1) telecommunications-based media, such as teleconferences, distance 
lectures, and (2) microprocessor-based media, for example, computerassisted instruction, computer games, intelligent tutoring systems, interactive, hypermedia, and compact (video) discs. Interactive learning media is a teaching delivery system that presents recorded video material with computer control to the audience (students) who not only hear and see video and sound but also provide active responses and those responses that determine the speed and sequence of presentation.

According to Soenarto (2009) quoted by Istiqlal (2017: 48), interactive was a process of empowering students to control the learning environment. In this context, the intended learning environment is learning by using a computer. Interactive classification within the scope of multimedia learning does not lie in the hardware system but instead refers to the characteristics of student learning in response to the stimulus displayed on a computer monitor screen. The sophistication of computer programs largely determines the quality of student interaction with computers.

\section{Adobe Flash Professional}

Adobe Flash Professional is one of the animation maker applications that are well known today. Various features and conveniences have caused Adobe Flash Professional to be a favorite and quite a popular animation program. Display interfaces, functions, and a variety of palette options, as well as a complete collection of tools, can help in the creation of exciting animation works. Adobe Flash Professional is used to create vector and animation images. The files generated from this software have the file 
extension.swf and can be played in web browsers that have Adobe Flash Player installed (Puardmi \& Ulva, 2017: 30).

In Adobe Flash Professional, there were also techniques for creating animations, Action Script facilities, filters, custom easing, and can include videos complete with FLV playback facilities. The advantage possessed by Adobe Flash Professional is being able to be given a little programming code either running alone to set the animation in it, or used to communicate with other programs, such as HTML, PHP, and databases with XML approaches that can be collaborated with the web because it has advantages, among others small in size of the output file (Puardmi \& Ulva, 2017: 30).

\section{Prayer skills}

According to Basyahril (1996: 9), prayer is a worship that includes speech and a particular body demonstration, starting with takbir and ending with salam (taslim). Prayer skills are more related to student's psychomotor in every movements. Psychomotor abilities are also known as process skills, which are skills that lead to the development of mental, physical, and social abilities that are fundamental to driving higher abilities in individual students. Susanto (2013) on Arpan (2016: 86) explains that "skill means the ability to use thoughts, reason, and actions effectively and efficiently to achieve a certain result, including creativity." Psychomotor domain measurement is carried out on learning outcomes in the form of appearance. However, the measurement of this aspect can be united or started with the measurement of the cognitive aspect at the same time 
(Arikunto, 2002: 122).

According to Suprapto (2009: 135), skill is the ability to use reason, thoughts and ideas, and creativity in doing, changing, or making something more meaningful to produce a value from work. In addition, skill is the ability to translate knowledge into practice, so that desired work outcomes are achieved.

Therefore, the development model that has been modified, adjusted and adapted needs to be done to increase the ability in prayer skills (Munir, 2017: 31-32). In this study, the process carried out using five stages, including the analysis phase, the design phase, the development stage, the implementation phase, and the assessment stage. The results obtained in this study were in the form of interactive media based on Adobe Flash Professional by using Adobe Flash CS6, as in Figure 1. 

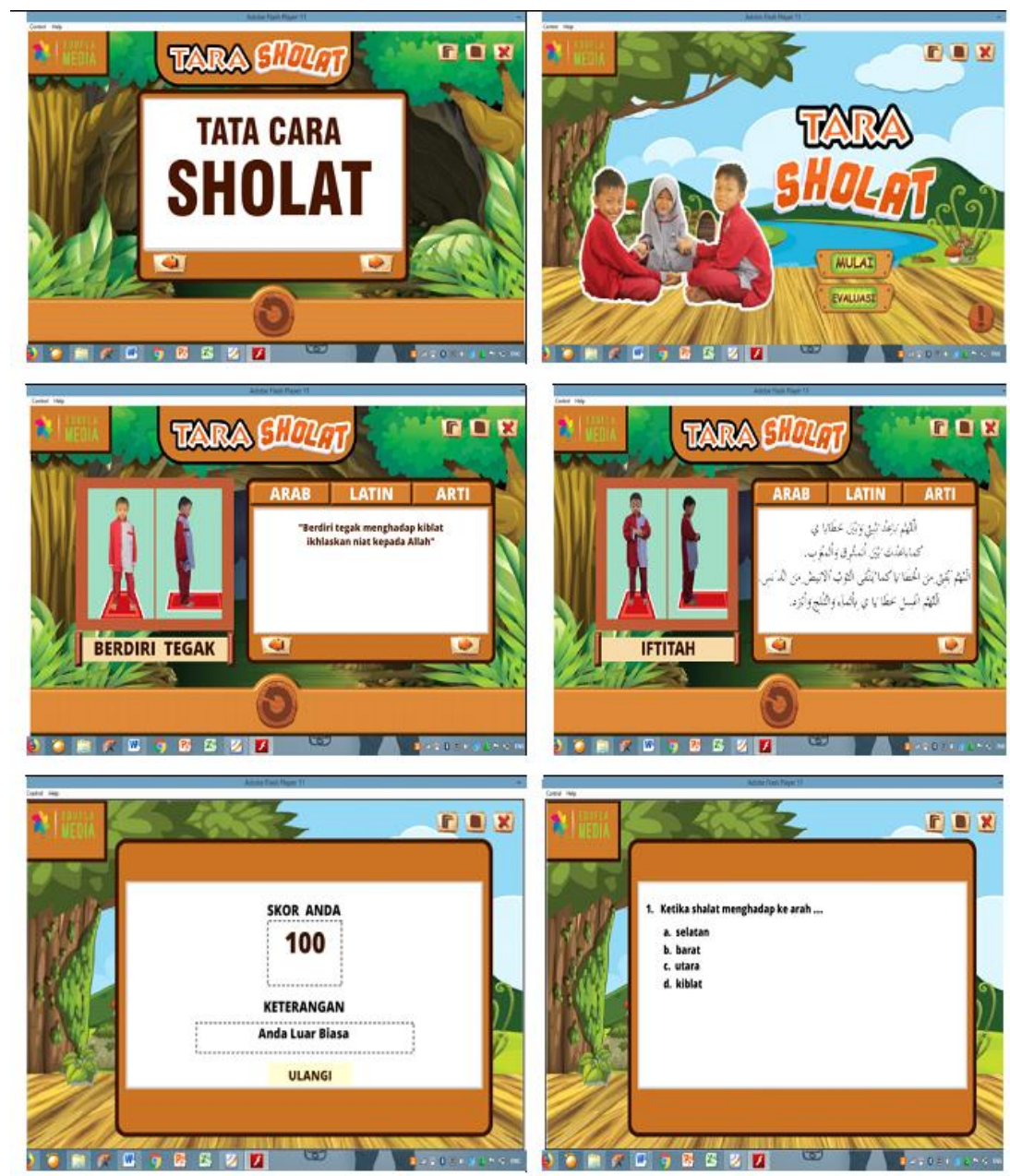

Figure 1. The procedure for prayers made with Adobe Flash Professional The process undertaken to produce this product began with collecting material in the form of prayer procedures used by MIM PK Blimbing Gatak Sukoharjo. From this book, the concept of making media design and media appearance was made. Adobe Flash Professional media was made by paying attention to students' knowledge with pictures, Arabic, and Latin recitations, as well as the meaning of the recitation so that in 


\section{Mudarrisa: Jurnal Kajian Pendidikan Islam, Vol. 11, No. 2, 2019}

addition to practical skills, students would understand the meaning of prayer reading.

The menu of the Tara Shalat media consists of the procedures for prayers in sequence according to the order of the movements and recitation of the prayer starting from takbiratul ihram until salam. The menu was divided into movements and recitation of the prayer as well as the procedures for prayer sequence. Then, Adobe Flash Professional media was added to the evaluation menu to test students' cognitive knowledge after seeing the procedure for prayer through Adobe Flash Professional. Students repeated the practice of prayer by paying attention to the material in this media. From this process, it can be concluded that this media product is worthy of being a learning medium after paying attention to some findings in the field with an increase in learning outcomes.

In this media development, data analysis was carried out to test product quality dimensions. This stage started with a sampling technique. This technique consisted of selecting and determining respondents, determining the sample size, and determining the objectives to be achieved from this test. The purpose of the product quality dimension test was to determine the extent of the product, which in this case was an adobe flashbased interactive media, fulfilling the criteria of eight dimensions of product quality according to Garvin's theory (1987), including performance, features, reliability, suitability, durability, service convenience, beauty, quality (Tjiptono, 2012: 143). However, not all of the 


\section{Mudarrisa: Jurnal Kajian Pendidikan Islam, Vol. 11, No. 2, 2019}

eight dimensions of product quality were used in this study.

The product quality dimensions test of Adobe Flash Professional products for the prayer procedure is written as in Table 1.

Table 1. Question List of Product Quality Dimension Test

No. Components assessed

1. The ability of adobe flash-based interactive media in conveying prayer movement material.

2. Clarity of content in interactive media

3. Image clarity on adobe flash-based interactive media

4. Text clarity on adobe flash-based interactive media

5. Interactive media capabilities to facilitate students in study

6. Ease in operating or running interactive media

7. A visual display (pictures, videos, or animations) to facilitate students when learning

8. The attraction of adobe flash-based interactive media narratives

9. Display text and writing form (fonts) in adobe flash interactive media

10. Combination, layout, and color selection in interactive media

Under certain conditions, the development is sufficient to arrive at a formative evaluation step. According to Dick \& Carey (2001) in Setyosari (2016: 288-289), a formative evaluation process consists of three steps:

Individual prototype testing of materials (one-to-one trying out)

This individual trial was conducted to obtain initial input about a particular product or design. Individual trials conducted on subjects of 1-3 people. After individual trials, the developer revised the product or design based on input from the results of the assessment or validation test. 
Small group tryout

This trial involved a subject consisting of $5-8$ subjects. The results of this small group trial were used to revise products, materials, or designs. The developer revised the product, material, or design in accordance with the input provided by the client or the target group.

Field tryout

This field trial involved subjects in a larger class involving 15-30 (a whole class of learners) or larger groups, namely the available classes. The results of this field trial were used to make a product, material, or final design revisions.

Table 2. Components Assessed in Individual Trials

\begin{tabular}{|c|c|c|c|c|c|}
\hline No. & $\begin{array}{c}\text { Components } \\
\text { assessed }\end{array}$ & $\begin{array}{c}\text { Scores of } \\
\text { respondents }\end{array}$ & $\begin{array}{l}\text { Total of }\left(\sum\right) \\
\text { score }\end{array}$ & $\begin{array}{c}\text { Average score } \\
\left(\sum \text { score/respon }\right. \\
\text { dent })\end{array}$ & $\begin{array}{c}\text { Percentage } \\
(\%)\end{array}$ \\
\hline 1. & $\begin{array}{l}\text { The ability of adobe } \\
\text { flash-based } \\
\text { interactive media in } \\
\text { conveying the } \\
\text { prayer material. }\end{array}$ & 545 & 14 & 4.7 & $93 \%$ \\
\hline 2. & $\begin{array}{l}\text { Clarity of } \\
\text { content in } \\
\text { interactive } \\
\text { media }\end{array}$ & 544 & 13 & 4.3 & $87 \%$ \\
\hline 3. & $\begin{array}{l}\text { Clarity of } \\
\text { animation on } \\
\text { adobe flash-based } \\
\text { interactive media }\end{array}$ & 444 & 12 & 4.0 & $80 \%$ \\
\hline 4. & $\begin{array}{l}\text { Text clarity on } \\
\text { adobe flash-based } \\
\text { interactive media }\end{array}$ & 545 & 14 & 4.7 & $93 \%$ \\
\hline
\end{tabular}




\begin{tabular}{|c|c|c|c|c|c|}
\hline 5. & $\begin{array}{l}\text { The ability of } \\
\text { interactive media to } \\
\text { facilitate students } \\
\text { in learning }\end{array}$ & 444 & 12 & 4.0 & $80 \%$ \\
\hline 6. & $\begin{array}{l}\text { Ease of } \\
\text { operating or } \\
\text { running } \\
\text { interactive } \\
\text { media }\end{array}$ & 544 & 13 & 4.3 & $87 \%$ \\
\hline 7. & $\begin{array}{l}\text { Visual display } \\
\text { (pictures, videos, } \\
\text { or animations) to } \\
\text { facilitate students } \\
\text { in learning }\end{array}$ & 445 & 13 & 4.3 & $87 \%$ \\
\hline 8. & $\begin{array}{l}\text { Attraction of adobe } \\
\text { flash-based } \\
\text { interactive media } \\
\text { narratives }\end{array}$ & 554 & 14 & 4,7 & $93 \%$ \\
\hline 9. & $\begin{array}{l}\text { Display text and } \\
\text { writing form (fonts) } \\
\text { in Adobe Flash } \\
\text { Interactive media }\end{array}$ & 444 & 12 & 4.0 & $80 \%$ \\
\hline 10. & $\begin{array}{l}\text { Combination, } \\
\text { layout, and color } \\
\text { selection in } \\
\text { interactive media }\end{array}$ & 455 & 14 & 4.7 & $93 \%$ \\
\hline
\end{tabular}

In addition, the trial media for Adobe Flash Professional prayer procedures were carried out in small groups with the display in Table 3.

Table 3. Components Assessed in Small Group Trials

\begin{tabular}{|c|c|c|c|c|}
\hline No. & $\begin{array}{l}\text { Components } \\
\text { assessed }\end{array}$ & $\begin{array}{c}\text { Scores of } \\
\text { respondents }\end{array}$ & $\begin{array}{cc}\text { Total of }\left(\sum\right) & \begin{array}{c}\text { Average score } \\
\text { score }\end{array} \\
\left(\sum \text { score } / \text { respon }\right. \\
\text { dent })\end{array}$ & $\begin{array}{c}\text { Percentage } \\
(\%)\end{array}$ \\
\hline
\end{tabular}




\begin{tabular}{|c|c|c|c|c|c|}
\hline 1. & $\begin{array}{l}\text { The ability of adobe } \\
\text { flash-based } \\
\text { interactive media in } \\
\text { conveying the } \\
\text { prayer material. }\end{array}$ & $\begin{array}{l}5445 \\
4345\end{array}$ & 34 & 4.3 & $85 \%$ \\
\hline 2. & $\begin{array}{l}\text { Clarity of } \\
\text { content in } \\
\text { interactive } \\
\text { media }\end{array}$ & $\begin{array}{l}4455 \\
5444\end{array}$ & 35 & 4.4 & $88 \%$ \\
\hline 3. & $\begin{array}{l}\text { Clarity of } \\
\text { animation on } \\
\text { adobe flash-based } \\
\text { interactive media }\end{array}$ & $\begin{array}{c}4454 \\
5455\end{array}$ & 36 & 4.5 & $90 \%$ \\
\hline 4. & $\begin{array}{l}\text { Text clarity on } \\
\text { adobe flash-based } \\
\text { interactive media }\end{array}$ & $\begin{array}{l}4444 \\
5545\end{array}$ & 35 & 4.4 & $88 \%$ \\
\hline 5. & $\begin{array}{l}\text { The ability of } \\
\text { interactive media to } \\
\text { facilitate students in } \\
\text { learning }\end{array}$ & $\begin{array}{c}4444 \\
5545\end{array}$ & 35 & 4.4 & $88 \%$ \\
\hline 6. & $\begin{array}{l}\text { Ease of } \\
\text { operating or } \\
\text { running } \\
\text { interactive } \\
\text { media }\end{array}$ & $\begin{array}{l}4445 \\
4554\end{array}$ & 35 & 4.4 & $88 \%$ \\
\hline 7. & $\begin{array}{l}\text { Visual display } \\
\text { (pictures, videos, } \\
\text { or animations) to } \\
\text { facilitate students } \\
\text { in learning }\end{array}$ & $\begin{array}{l}4554 \\
4555\end{array}$ & 37 & 4.6 & $93 \%$ \\
\hline 8. & $\begin{array}{l}\text { Attraction of adobe } \\
\text { flash-based } \\
\text { interactive media } \\
\text { narratives }\end{array}$ & $\begin{array}{r}5455 \\
5355\end{array}$ & 37 & 4.6 & $93 \%$ \\
\hline 9. & $\begin{array}{l}\text { Display text and } \\
\text { writing form (fonts) } \\
\text { in Adobe Flash } \\
\text { Interactive media }\end{array}$ & $\begin{array}{l}5444 \\
4555\end{array}$ & 36 & 4.5 & $90 \%$ \\
\hline
\end{tabular}




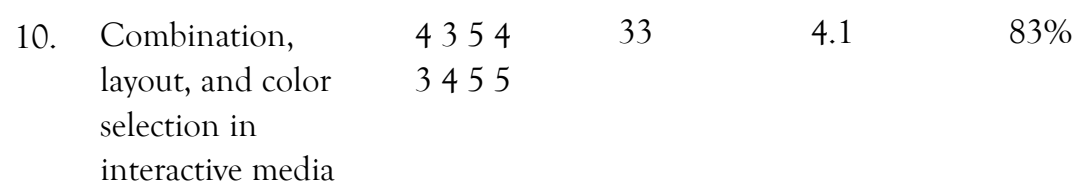

Average Percentage

Meanwhile, the trial media for prayer procedures using Adobe Flash Professional was also conducted. The results of trials in large groups are shown in the table below.

Table 4. Components Assessed in Large Group Trials

\begin{tabular}{|c|c|c|c|c|c|}
\hline No. & $\begin{array}{l}\text { Components } \\
\text { assessed }\end{array}$ & $\begin{array}{c}\text { Scores of } \\
\text { respondents }\end{array}$ & $\begin{array}{l}\text { Total of }\left(\sum\right) \\
\text { score }\end{array}$ & $\begin{array}{c}\text { Average score } \\
\text { ( } \begin{array}{c}\text { score/respon } \\
\text { dent })\end{array}\end{array}$ & $\begin{array}{c}\text { Percentage } \\
(\%)\end{array}$ \\
\hline 1. & $\begin{array}{l}\text { The ability of adobe } \\
\text { flash-based } \\
\text { interactive media in } \\
\text { conveying the } \\
\text { prayer material. }\end{array}$ & $\begin{array}{c}544 \\
55444 \\
4554 \\
54544 \\
445\end{array}$ & 88 & 4.4 & $88 \%$ \\
\hline 2. & $\begin{array}{l}\text { Clarity of } \\
\text { content in } \\
\text { interactive } \\
\text { media }\end{array}$ & $\begin{array}{c}5445 \\
54444 \\
55454 \\
54445 \\
5\end{array}$ & 89 & 4.5 & $89 \%$ \\
\hline 3. & $\begin{array}{l}\text { Clarity of } \\
\text { animation on } \\
\text { adobe flash-based } \\
\text { interactive media }\end{array}$ & $\begin{array}{c}4444 \\
54454 \\
44454 \\
44444 \\
5\end{array}$ & 84 & 4.2 & $84 \%$ \\
\hline 4. & $\begin{array}{l}\text { Text clarity on } \\
\text { adobe flash-based } \\
\text { interactive media }\end{array}$ & $\begin{array}{c}4435 \\
54455 \\
44453 \\
54444 \\
4\end{array}$ & 84 & 4.2 & $84 \%$ \\
\hline
\end{tabular}




\begin{tabular}{|c|c|c|c|c|c|}
\hline 5. & $\begin{array}{l}\text { The ability of } \\
\text { interactive media to } \\
\text { facilitate students in } \\
\text { learning }\end{array}$ & $\begin{array}{c}4454 \\
54454 \\
44545 \\
44444 \\
5\end{array}$ & 86 & 4.3 & $86 \%$ \\
\hline 6. & $\begin{array}{l}\text { Ease of } \\
\text { operating or } \\
\text { running } \\
\text { interactive } \\
\text { media }\end{array}$ & $\begin{array}{c}4454 \\
54445 \\
44545 \\
44444 \\
5\end{array}$ & 86 & 4.3 & $86 \%$ \\
\hline 7. & $\begin{array}{l}\text { Visual display } \\
\text { (pictures, videos, } \\
\text { or animations) to } \\
\text { facilitate students } \\
\text { in learning }\end{array}$ & $\begin{array}{c}5545 \\
55554 \\
55554 \\
45545 \\
5\end{array}$ & 95 & 4.8 & $95 \%$ \\
\hline 8. & $\begin{array}{l}\text { Attraction of adobe } \\
\text { flash-based } \\
\text { interactive media } \\
\text { narratives }\end{array}$ & $\begin{array}{c}5445 \\
54445 \\
45455 \\
54444 \\
5\end{array}$ & 89 & 4.5 & $89 \%$ \\
\hline 9. & $\begin{array}{l}\text { Display text and } \\
\text { writing form (fonts) } \\
\text { in Adobe Flash } \\
\text { Interactive media }\end{array}$ & $\begin{array}{l}5455 \\
54444 \\
45545 \\
54455\end{array}$ & 91 & 4.6 & $91 \%$ \\
\hline
\end{tabular}

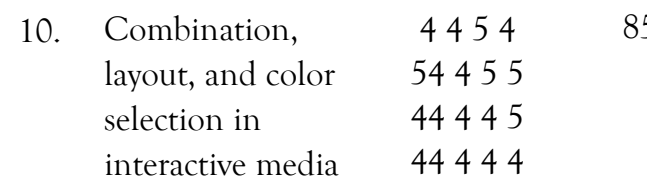

\begin{tabular}{cc}
4 & \\
\hline Average Percentage & $87.7 \%$ \\
\hline
\end{tabular}

The data obtained during an individual trial consisting of three students of Class 2 MIM PK Blimbing Gatak Sukoharjo revealed that the average overall percentage of the quality of interactive media on small group prayer procedures reached $87.3 \%$. It shows that interactive media products were of high qualification or feasible and did not require 


\section{Mudarrisa: Jurnal Kajian Pendidikan Islam, Vol. 11, No. 2, 2019}

revision. The data obtained during a small group trial consisting of eight students of Class 2 MIM PK Blimbing Gatak Sukoharjo students found that the average percentage in overall regarding the quality of interactive media prayer skills reached $88.6 \%$. It shows that interactive media products were high or good qualifications and did not require revision.

From the data generated during a large group trial consisting of twenty students of Class 2MIM PK Blimbing Gatak Sukoharjo, it was known that, on average, the overall percentage of the quality of interactive media prayer skills reached $87.7 \%$. It shows that the interactive media products for the procedure of prayer were at high or good qualifications and did not require revision. Thus, this interactive media can be used in improving prayer skills for the 2nd grade of MIM PK Blimbing Gatak Sukoharjo.

\section{CONCLUSION}

From the results of research that has been done, this Adobe Flash-based interactive media has been successfully tested for its effectiveness, efficiency, and attractiveness. This interactive media presents the process of movement and recitation of prayer both in Arabic letters and Latin letters and their meanings. Interactive media is easy to operate with computer media. This interactive media has fulfilled the needs of teachers and students to improve prayer skills for students of grade 2 in MIM PK Blimbing Gatak Sukoharjo. Besides, additional instruments in interactive media (such as music, images, animation, and sound effects) can attract students' attention and eliminate boredom in learning. This interactive 
media can increase student interest in learning so that learning objectives can be achieved.

\section{REFERENCES}

Arikunto, S. (2002). Dasar-dasar Evaluasi Pendidikan. Jakarta: Bumi Aksara. Arsyad, A. (2014). Media Pembelajaran. Jakarta: Rajawali Pers.

Arpan, M., Bibi, S., \& Sulistiyarini, D. (2016). Hubungan Kemampuan Kognitif dengan Kemampuan Psikomotor Mahasiswa dalam Mempersiapkan Diri untuk Workshop Komputer Prodi PTIK. Jurnal Pendidikan Informatika dan Sains, 5(1),82-95.

Atiaturrahmaniah \& Ibrahim, D.S.M. (2017). Pengembangan Media Pembelajaran Berbasis Adobe Flash dengan Penerapan TeoriVan Hiele. Jurnal Didikan (Wahana Ilmiah Pendidikan Dasar). Vol.1, No.1: Januari-Juni2017. 1-13.

Cahyono, G. (2019). Media Pembelajaran Teori dan Praktik Pembelajaran. Sukoharjo: Oase Pustaka.

Damayanti, P., \&Ulva, S. M. (2017). Pengembangan Media Adobe Flash CS3 Pada Konsep Bunyi Dengan Mengaplikasikan Model Instructional Games.Jurnal Ilmu Pendidikan Dasar KEGURU,1(1), $28-42$.

Hamidi, N. (2017). Pengembangan Media Pembelajaran Interaktif Pendidikan Agama Islam Berbasis Adobe Flash Professional Cs6 Untuk Mendukung Implementasi Kurikulum 2013. Jurnal Pendidikan Agama Islam, 14(1), 109-130. 
Maulidta, H \& Sukartiningih, W. (2018) Pengembangan Media Interaktif Berbasis Adobe Flash untuk Pembelajaran Menulis Teks Eksposisi Siswa Kelas III SD. JPGSD, 6(05), 681-692.

Istiqlal, M. (2017). Pengembangan Multimedia Interaktif dalam Pembelajaran. Jurnal Ilmiah Pendidikan Matematika, 2(1), 143-154. Mujiburrachman. (2016). Pola Pembinaan Keterampilan Shalat Anak Dalam Islam. Jurnal Mudarrisuna, 6(2), 185-204.

Setyosari, P. (2016). Metode Penelitian Pendidikan dan Pengembangan. Jakarta: Prenamedia Group.

Sugiyono, (2011). Metode Penelitian Kuantitatif, Kualitatif dan R\&D. Jakarta: Alfabeta.

Sujadi, (2003). Metodologi Penelitian Pendidikan. Jakarta: Rineka Cipta.

Sugandi, A. (2000). Teori Pembelajaran. Bandung: Remaja Rosdakarya.

Suprapto, T. (2009). Pengantar Teori dan Manajemen Komunikasi. Yogyakarta: MedPress.

Tjiptono, F, \& Chandra, G. (2012). Pemasaran Strategik. Yogyakarta: Andi. Yaumi, M. (2018). Media dan Teknologi Pembelajaran. Jakarta: Prenamedia. 